OPEN ACCESS

Edited by:

José Alexandre Ferreira,

Portuguese Oncology Institute,

Portugal

Reviewed by:

Jiayin Tang,

Shanghai Jiao Tong University, China

Enhao Zhao,

Shanghai Jiao Tong University, China

Yuan Li,

Southern Medical University, China

*Correspondence:

Xia Xie

xiexia0128@163.com

Shiming Yang

shimingyang@yahoo.com

${ }^{\dagger}$ These authors have contributed equally to this work

Specialty section:

This article was submitted to

Molecular Diagnostics

and Therapeutics,

a section of the journal

Frontiers in Molecular Biosciences

Received: 03 January 2021

Accepted: 10 March 2021

Published: 11 May 2021

Citation:

Wang $C$, Hu Y, Yang H, Wang S,

Zhou B, Bao Y, Huang Y, Luo Q,

Yang C, Xie $X$ and Yang S (2021)

Function of Non-coding RNA

in Helicobacter pylori-Infected Gastric Cancer. Front. Mol. Biosci. 8:649105.

doi: 10.3389/fmolb.2021.649105

\section{Function of Non-coding RNA in Helicobacter pylori-Infected Gastric Cancer}

\author{
Chao Wang ${ }^{\dagger}$, Yiyang Hut, Huan Yang, Sumin Wang, Bo Zhou, Yulu Bao, Yu Huang, \\ Qiang Luo, Chuan Yang, Xia Xie* and Shiming Yang*
}

Department of Gastroenterology, Xinqiao Hospital, Third Military Medical University, Chongqing, China

Gastric cancer is a common malignant tumor of the digestive system. Its occurrence and development are the result of a combination of genetic, environmental, and microbial factors. Helicobacter pylori infection is a chronic infection that is closely related to the occurrence of gastric tumorigenesis. Non-coding RNA has been demonstrated to play a very important role in the organism, exerting a prominent role in the carcinogenesis, proliferation, apoptosis, invasion, metastasis, and chemoresistance of tumor progression. $H$. pylori infection affects the expression of non-coding RNA at multiple levels such as genetic polymorphisms and signaling pathways, thereby promoting or inhibiting tumor progression or chemoresistance. This paper mainly introduces the relationship between $\mathrm{H}$. pylori-infected gastric cancer and non-coding RNA, providing a new perspective for gastric cancer treatment.

Keywords: non-coding RNA, Helicobacter pylori infection, gastric cancer, genetic polymorphisms, chemoresistance

\section{INTRODUCTION}

As one of the most common digestive tumors worldwide, the morbidity and mortality of gastric cancer (GC) are increasing annually (Ferlay et al., 2019). The associated risk factors include smoking, overweight, salty food consumption, Epstein-Barr virus infection, and exposure to asbestos. Surgery, chemotherapy, and chemoradiation are the main treatments for GC, but the prognosis is not satisfactory. Numerous studies have shown that the pathogenesis and progression of GC are closely related to those of Helicobacter pylori infection (Helicobacter and Cancer Collaborative Group [HCCG], 2001). H. pylori is regarded as a gram-negative microaerophilic

Abbreviations: ABCG2, ATP-binding cassette, subfamily G, member 2; CagA, cytotoxin-related gene A; cag-PAI, cag pathogenicity island; ceRNA, competing endogenous RNA; CHRM2, cholinergic receptor, muscarinic 2; CIC, cancerinitiating cell; circRNAs, circular RNAs; EMT, epithelial-mesenchymal transition; FoxM1, Forkhead box protein M1; FZD7, Frizzled 7; GC, gastric cancer; GClnc1, GC-associated lncRNA 1; GKN1, Gastrokine 1; GML, gastric MALT lymphoma; H. pylori, Helicopter pylori; HIPK2, homeodomain-interacting protein kinase 2; IRAK1, IL-1 receptor-associated kinase 1; JAK2, Janus kinase 2; KLF4, Krüppel-like transcription factor; lncRNAs, long non-coding RNAs; LPS, lipopolysaccharide; miRNAs, microRNAs; MMR, mismatch repair; PBP1A, penicillin-binding protein 1A; piRNAs, PiWi-interacting RNAs; PRNCR1, prostate cancer non-coding RNA 1; RAGE, receptor for advanced glycation end product; RepG, regulator of polymeric G-repeats; siRNAs, small interfering RNAs; SMARCD1, SWI/SNF chromatin remodeling complex subunit; SMOX, spermine oxidase; snoRNAs, small nucleolar RNAs; SOX2OT, SOX2 overlapping transcript; SSRs, simple sequence repeats; SWI/SNF, SWItch/Sucrose Non-fermentable; TCS, two-component system; THAP9-AS1, THAP domain-containing 9 antisense RNA 1; TRAF6, tumor necrosis factor receptor-associated factor 6; tsRNAs, tRNA-derived small RNAs; ZEB1, zinc-finger E-box-binding homeobox 1; ZEB2, zinc finger E-box binding homeobox 2. 
bacterium that is capable of entering the human body early and colonizing the mucosal area of the stomach for a long time (Blaser and Atherton, 2004). H. pylori infection is associated with inducing chronic gastritis, peptic ulcer, GC, and mucosaassociated lymphoid tissue (MALT) lymphoma (Petra et al., 2017). Various clinical analysis and basic biological research have revealed that patients with $H$. pylori-positive GC have more lymph node metastasis and a worse prognosis than have negative patients. Therapy for $H$. pylori eradication can effectively prevent GC (Choi et al., 2018; Mera et al., 2018; Suzuki and Matsuzaki, 2018). The Kyoto Global Consensus Report recommends that regardless of age or severity of gastric mucosal lesions, especially in areas with a high incidence of GC, all $H$. pylori-infected patients should be treated (Sugano et al., 2015; Malfertheiner et al., 2017; Sugano, 2019).

Non-coding RNA (ncRNA) refers to RNA that does not encode protein, which has been divided into long ncRNAs (lncRNAs) and short ncRNAs including microRNAs (miRNAs), PiWi-interacting RNAs (piRNAs), small nucleolar RNAs (snoRNAs), small interfering RNAs (siRNAs), tRNAderived small RNAs (tsRNAs), circular RNAs (circRNAs), and heterochromatin-derived 24nt small RNA in plants according to their length. These RNAs are derived from genomic transcription, but they are not translated into proteins; and they play their respective biological roles at the RNA level. Among these RNAs, lncRNA, miRNA, and some special small ncRNAs (sncRNAs) are mainly involved in the progress of $H$. pylori-induced GC. LncRNA is an ncRNA that is greater than 200 nucleotides in length. It has many known functions, including transcriptional interference, regulation of alternative splicing, generation of endogenous siRNA, regulation of protein activity, and alteration of protein positioning (Wilusz et al., 2009). In addition, many studies have shown that lncRNA is more tissue-specific than mRNA, indicating that it is also closely related to the function of the tissue (Ransohoff et al., 2018). MiRNA is a non-coding 18- to 24-nucleotide RNA that regulates gene expression at the mRNA level. Mature miRNA can directly bind to the $3^{\prime}$ UTR region of the target gene to rapidly degrade mRNA or inhibit protein expression (Bartel, 2004; Acunzo et al., 2015; Shomali et al., 2017).

This review mainly summarizes the mechanism of ncRNA in H. pylori-infected GC. H. pylori infection modulates expression of ncRNA and changes the expression of related target genes. Their impact on tumor progression and drug resistance treatment has been categorized and summarized, and a new perspective for clinical treatment is provided.

\section{HELICOBACTER PYLORI PLAYS A VITAL ROLE IN GASTRIC CANCER}

The prevalence of Helicobacter pylori presents large regional differences worldwide, which is related to factors such as geography and basic health conditions. $H$. pylori survival is facilitated in an acidic environment, and it colonizes in the gastric mucosa by virtue of its spiral shape, exercise ability, adhesion factors, and urease and ammonia production, subsequently producing a complex inflammatory response, damaging the gastric mucosa, and subsequently producing digestive diseases via the expression of various pathogenic markers such as cytotoxinrelated gene A (CagA), BabA adhesin, and empty vesicular toxin (VacA) (Backert et al., 2017). Flagellar movement and various adhesion factors (AlpA/B, BabA, OipA, SabA, and HopQ) promote $H$. pylori adhesion to epithelial cells. Urease converts urea into ammonia, making the environment in which bacteria live weakly acidic and thereby reducing the level of intestinal bacteria. VacA produces proteins that are toxic to gastrointestinal epithelial cells (Morello, 1999; Amieva and El-Omar, 2008; Atherton and Blaser, 2009; Safaralizadeh et al., 2017; Su et al., 2019). The virulence factor CagA is involved in various signal transduction processes (Pachathundikandi et al., 2013). All these determine the importance of H. pylori in GC.

\section{NON-CODING RNA INFLUENCES THE PROGRESSION AND TREATMENT OF HELICOBACTER PYLORI-INFECTED GASTRIC CANCER}

\section{Small RNA}

Small ncRNAs produced by bacteria are classified as sRNAs, which exert their heterogeneity in a eubacterial environment. The length of sRNA ranges from 50 to 250 nucleotides, and its effect on biological process and its target genes have been identified by various methods in vitro and in vivo (Vogel and Wagner, 2007; Sharma and Vogel, 2009). The present mechanism displays a binding function to protein or an antisense RNA role on trans-encoded mRNAs, in which the latter usually shows translation inhibition or activation through imperfect complementarity between sRNA and its targets, modulating the stability and/or accessibility on the translational machinery (Majdalani et al., 2005; Livny and Waldor, 2007). The sRNAs have also been reported to participate in acid resistance in Escherichia coli (Opdyke et al., 2004; Tramonti et al., 2008), virulence of pathogens (Geissmann et al., 2006; Romby et al., 2006), and iron homeostasis (Chen and Crosa, 1996; Dühring et al., 2006). Helicobacter pylori also produced sRNAs that participate in the progression of GC. A large number of sRNAs were found in an analysis of $H$. pylori primary transcriptome study (Rieder et al., 2012). Reports show that bacterial Sm-like protein Hfq is necessary for effective function of sRNA (Valentin-Hansen et al., 2004). However, Hfq, an RNA molecular chaperone, is absent in $H$. pylori. By facilitating the pairing of small RNAs with their target mRNAs, Hfq can affect translation and turnover rates of specific transcripts and contribute to complex posttranscriptional networks (Vogel and Luisi, 2011). Thus, H. pylori was previously thought to lack ribosomal regulation (Mitarai et al., 2007). Because of the lack of $\mathrm{Hfq}$ in $H$. pylori, two methods were designed to identify other auxiliary proteins in sRNA-mediated regulation, and RNA-protein interactions were identified between ribosomal protein S1 and various mRNA and sRNA of $H$. pylori, which confirmed that $H$. pylori can control their gene expression via 
ribosomal regulation (Rieder et al., 2012). The identification of H. pylori sRNA and the mechanism of ribose regulation have potential effects on the virulence mechanism and stress response (Pernitzsch and Sharma, 2012), which may be associated with the development of GC.

The HP0165-HP0166 two-component system (TCS) in $H$. pylori participates in the increased expression of urease genes, while whether the increased activity of urease is beneficial or harmful to organism is determined by the presence or absence of acid in the stomach (Clyne et al., 1995; Meyer-Rosberg et al., 1996; Pflock et al., 2004, 2005). HP0165 is the membrane sensor, while HP0166 is its response regulator. For survival and colonization on the gastric surface, $H$. pylori regulated TCS to change urease activity according to the different intragastric $\mathrm{pH}$ values (Wen et al., 2006). A novel cis-encoded antisense sRNA, identified as $5^{\prime}$ ureB-sRNA, downregulates ure $\mathrm{AB}$ expression by enhancing transcription termination of $5^{\prime}$ region of ureB, which validates through an in vitro transcription assay (Wen et al., 2013). However, HP0165-HP0166 TCS negatively regulates expression of $5^{\prime}$ ureB-sRNA to increase ureAB expression at low $\mathrm{pH}$ values and enhances $5^{\prime}$ ureB-sRNA to decrease ure $\mathrm{AB}$ expression and to decrease urease activity at high $\mathrm{pH}$ values (Wen et al., 2011).

CncR1, a rich and conserved sRNA encoded by the virulenceassociated cag pathogenicity island (cag-PAI) of $H$. pylori, interacts with the fliK mRNA and downregulates bacterial motility and adhesion ability, significantly impairing bacterial adhesion to host gastric cell lines (Vannini et al., 2016). The sRNA
RepG (Regulator of polymeric G-repeats) in H. pylori was also found to directly target a variable homopolymeric G-repeat in the leader of the TlpB chemotaxis receptor mRNA, which contains simple sequence repeats (SSRs) (Pernitzsch et al., 2014). Phase variation in hypermutable SSRs contributes to host adaptation of bacterial pathogens. In this way, sRNA may ensure the survival of H. pylori in the human body, leading to severe disease. In fact, many features of the sRNA are unknown and worth exploring, as they may have important implications for $H$. pylori-induced GC.

Helicobacter pylori not only plays a role via its own nosotoxin but also participates in the homeostasis regulation of intestinal flora, and $H$. pylori eradication treatment has a significant effect on the change in intestinal flora (Zhang et al., 2016). For example, after the application of PPI for $H$. pylori eradication treatment, the abundance of streptococci, enterococci, staphylococci, and micrococci in the intestinal flora increased while clostridia decreased (Freedberg et al., 2015). A schematic diagram of the pathogenic mechanism of $H$. pylori is shown (Figure 1).

\section{Long Non-coding RNA}

The Mechanism of Long Non-coding RNAs in
Helicobacter pylori-Infected Gastric Cancer

Polymorphisms in lncRNAs have been reported to influence the splicing and stability of mRNA (Burd et al., 2010; Chung et al., 2011), and the special region known as the "gene desert" was discovered to participate in prostate cancer, colorectal cancer,

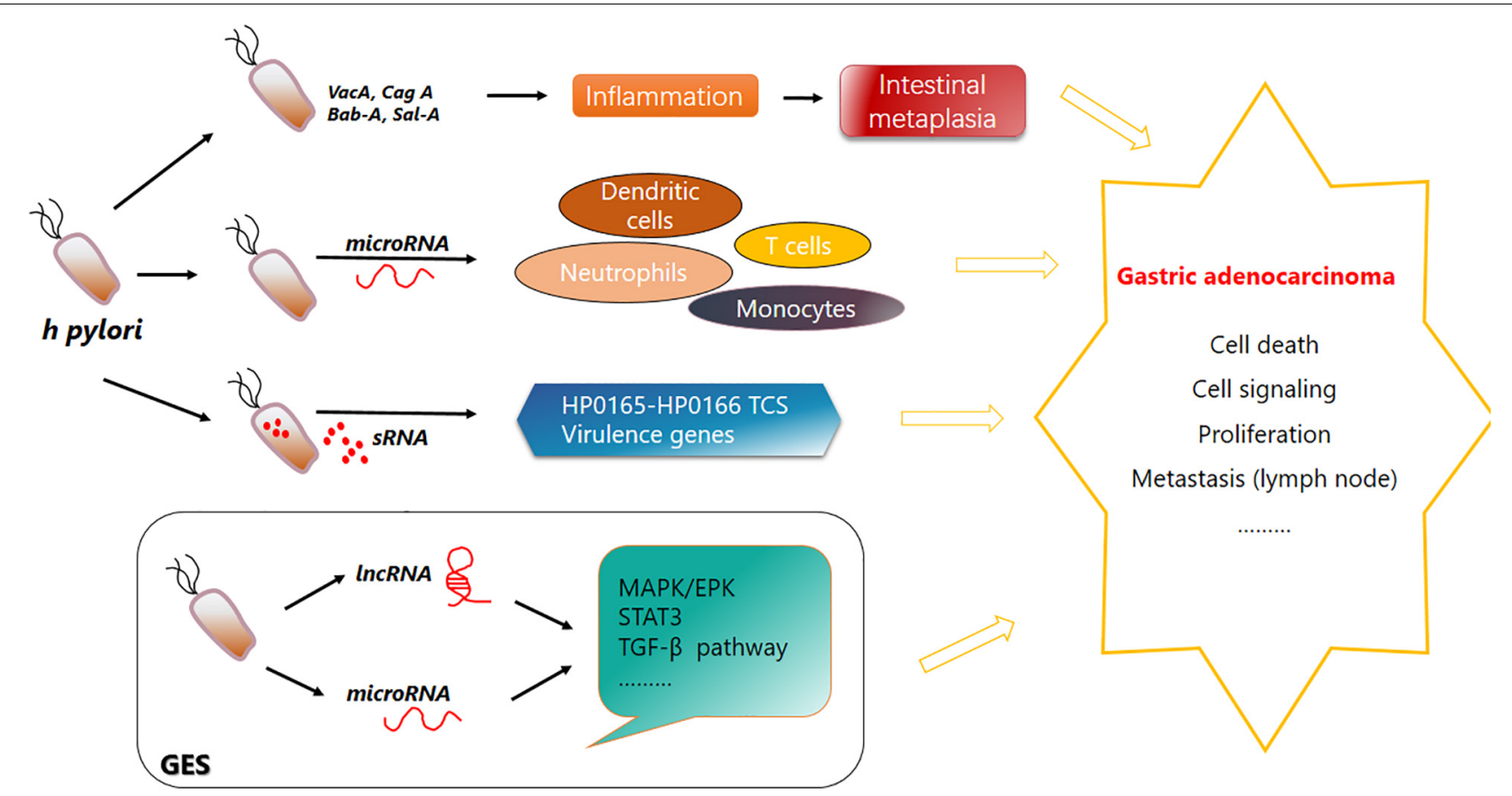

FIGURE 1 | Function of Helicobacter pylori in gastric carcinogenesis. H. pylori secretes Bab-A, Sab-A, VacA, CagA, and other substances to help invade and colonize in the human gastric mucosa and cause chronic inflammation and superficial gastritis. Its infection leads to a variety of signaling events. Immune cells such as dendritic cells, neutrophils, monocytes, and T cells can produce various microRNAs. Specific sRNA can combine with the HP0165-HP0166 two-component system to regulate the $\mathrm{pH}$ adaptability of $\mathrm{H}$. pylori to help its inhabitation and colonization in stomach. $H$. pylori invasion also causes upregulation or downregulation of IncRNAs and microRNAs. Their complex regulatory network is disrupted, and pathways are affected. Bab-A, blood-group antigen binding adhesion; Sab-A, sialic acid binding protein $A$. 
breast cancer, and H. pylori-infected GC (Tomlinson et al., 2007; Ghoussaini et al., 2008; Zhang et al., 2010; He et al., 2017). A case-control study revealed that rs 16901946 of prostate cancer ncRNA 1 (PRNCR1) was associated with GC risk, which could be increased by $H$. pylori infection. Another case-control study showed that LINC00673 rs11655237 with GG genotype was more susceptible to $H$. pylori infection.

Based on the database analysis of The Cancer Genome Atlas (TCGA), a competing endogenous RNA (ceRNA) network was constructed, and four lncRNAs (LINC01254, LINC01287, LINC01524, and U95743.1) showed higher expression in H. pylori infection-positive GC patients, and the results were validated by real-time PCR. In contrast, microarray analysis showed different results, in which $23 \operatorname{lncRNAs}$ were upregulated and 21 downregulated [such as lncRNA NR_026827 (Zhong et al., 2018)] in H. pylori-infected GES-1 gastric epithelial cell, and some of the results were also found by PCR (Yang et al., 2015; Polakovicova et al., 2018). Among them, a recent network analysis showed that RP11-169F17.1 and RP11-669N7.2 were related to $H$. pylori infection-induced gastritis, as their targets showed great overlap with $H$. pylori-infection associated genes (Yang and Song, 2019). Seven upregulated and 17 downregulated lncRNAs were found using GSE5081 and GSE66229 (Zhang et al., 2020). LINC00152 and H19 were previously shown to be significantly upregulated in GC patients' blood samples and cancer tissues, which was validated to be a risk factor in the diagnosis and prognosis of GC with $\mathrm{H}$. pylori infection (Pang et al., 2014; Yang T. et al., 2016).

Regarding the underlying mechanism, the lncRNA-RNA network was constructed based on the profiling of $H$. pyloriinfected GES-1 cells, for which a concrete example is the downregulation of MUC2 by lncRNA AF147447 to suppress cell proliferation and invasion in the $H$. pylori-infection background (Zhu et al., 2015; Zhou et al., 2016). According to the RNAseq analysis of $H$. pylori-infected AGS cells, THAP domaincontaining nine antisense RNA 1 (THAP9-AS1) was found to be induced by $H$. pylori infection and to promote the migration and proliferation of GC cells (Jia et al., 2019). The expression level of lnc-SGK1 was elevated as a consequence of $H$. pylori infection and a high-salt diet. Lnc-SGK1 increases the transcription of SGK1 in a cis-regulatory manner, which activates JunB and disrupts $\mathrm{T}$ helper cell differentiation (Yao et al., 2016).The results of lncRNA were mainly derived from database analysis, and there was a lack of clinical studies.

\section{Long Non-coding RNAs Influence the Drug Resistance and Prognosis of Helicobacter pylori-Infected Gastric Cancer}

Chemotherapy can achieve a certain effect on the treatment of GC, but the acquisition of drug resistance will lead to the failure of chemotherapy in GC patients. Although the mechanism of anticancer drug resistance has been extensively studied, its specific mechanism has not yet been elucidated. In recent years, more and more studies have shown that ncRNA plays a regulatory role in the generation and maintenance of drug resistance. Cisplatin is a commonly used drug in the treatment of GC (Zheng et al., 2017), but its resistance has been found to be closely related to ncRNA. It is reported that lncRNA BCAR4 expression was enhanced in cisplatin-resistant cell strain SGC7901/DDP. And the drug resistance of cell strains was positively correlated with the expression level of BCAR4 (Wang L. et al., 2017). And it was found that the removal of IncRNA ANRIL inhibited the development of multidrug resistance (MDR) in GC cells (Lan et al., 2016). At present, many ncRNAs have been found to play a regulatory role in chemotherapy resistance of GC, and even some ncRNAs play a relatively key role. Therefore, ncRNAs can be used to be a kind of candidate drugs to develop new molecular targeted therapy strategies or reverse the resistance of GC cells to chemotherapy.

Besides, IncRNA is also related to prognosis of GC. Researchers found that the knockdown of IncRNA CASC19 inhibited proliferation and migration of GC cells in vitro. And their multivariate Cox analysis confirmed that CASC19 overexpression was an independent prognostic factor for overall survival (Wang et al., 2019). A set of 24-lncRNAs significantly associated with disease-free survival (DFS) was even established and used to improve prognosis prediction of GC (Zhu et al., 2016). Actually, miRNAs have been studied for much longer than lncRNAs. And at the same time, there are more research results.

\section{MicroRNA}

\section{The Mechanism of MicroRNAs in Helicobacter pylori-Infected Gastric Cancer}

From the perspective of polymorphism, miR-27a rs895819 and $H$. pylori have shown an interaction effect in gastric carcinogenesis ( $\mathrm{Xu}$ et al., 2017). In contrast, miR-124a, miR$34 \mathrm{~b}$, and miR-34c have been reported to be downregulated in H. pylori-infected gastric mucosa, and miR-124a downregulation is associated with $\mathrm{CpG}$ hypermethylation of the miR-124a3 locus and higher IL-8 expression (Tahara et al., 2019).Additionally, miR-124 downregulation leads to elevated expression of spermine oxidase (SMOX) as it directly binds directly to the $3^{\prime}$ UTR of SMOX mRNA, and this process can be reversed by 5-azacytidine (Murray-Stewart et al., 2016). H. pylori eradication induces decreased methylation $(p<0.01)$ and increased expression ( $p=0.03$ ) of miR-133a (Hyun Lim et al., 2018). MiR-204 is upregulated in GC compared with $H$. pylori-positive gastritis $(p<0.004)$ (Kuo et al., 2019).Other examples about phenotype changes associated with miRNA in $H$. pylori-infected GC have been mentioned in Table 1.

Based on the mechanism, the change in miRNA expression is closely related to $H$. pylori-produced virulence factors. MiR-34a was found to be significantly reduced in the H. pylori + GC group by rTip- $\alpha$ (a toxin secreted by $H$. pylori), while its overexpression decreased the level of TLP4, TNF- $\alpha$, and IL-6. Viability was enhanced by rTip- $\alpha$ but decreased by miR34a, which induces cell proliferation (Wang et al., 2018). Lipopolysaccharide (LPS) from H. pylori activates sp1 to increase MDM2 expression, while MDM2 represses p63 to inhibit Dicer, leading to inhibition of miR-106b and miR-375. JAK1 and STAT3 are downstream target genes of miR-106b (Ye et al., 2015). MiR-134 targets FoxM1 (Forkhead box protein M1) to suppress the proliferation, invasion, and 
TABLE 1 | Associated phenotype alteration in non-coding RNA.

\begin{tabular}{lcc}
\hline MicroRNA & Phenotype change & References \\
\hline MiR-27 & rs895819 & Xu et al., 2017 \\
MiR-124a & CpG hypermethylation & Tahara et al., 2019 \\
MiR-129-2 & Methylation & Watari et al., 2019 \\
MiR-133a & Methylation & Hyun Lim et al., 2018 \\
MiR-149 & Hypermethylation & Li et al., 2015 \\
MiR-200a/b & Methylation & Choi et al., 2020 \\
MiR-204(TRPM3) & Methylation & Chen et al., 2019 \\
MiR-210 & Methylation & Kiga et al., 2014 \\
MiR-490-3p(CHRM2) & Methylation & Shen et al., 2015; Cho et al., 2016 \\
MiR-4795 & rs1002765 & Wu et al., 2017 \\
let-7b & rs8111742 & Isomoto et al., 2012; Hayashi et al., \\
& & 2013; Wu et al., 2017 \\
IncPRNCR1 & rs16901946 & He et al., 2017 \\
LINC00673 & rs11655237 & Zhao et al., 2019 \\
\hline
\end{tabular}

epithelial-mesenchymal transition (EMT) of GC cell, while H. pylori $i_{\mathrm{Cag} A}+\mathrm{P}+[\mathrm{CagA}$ and penicillin-binding protein $1 \mathrm{~A}$ (PBP1A) mutation-positive] infection suppresses miR134 expression when compared with $H$. pylori CagA $_{2} / \mathrm{P}-$ tissues (Huang et al., 2019). The miR-155 was found to be upregulated by CagA (cytotoxin-associated gene A) from H. pylori, and it can restrict KLF4 (Krüppel-like transcription factor) expression to promote EMT and tumor growth (Ou et al., 2019).

Many signaling pathways are involved in the regulation between $H$. pylori infection and miRNA. $H$. pylori infection causes activation of the NF- $\kappa \mathrm{B}$ signaling pathway, which leads to miR-7 downregulation, while miR-7 targets the I $\mathrm{B}$ kinase $\mathrm{IKK} \varepsilon$ to repress RELA activation. In return IKKe and RELA repress miR-7. Thus, the repression of RELA and FOS is released, and cell proliferation and tumorigenesis are promoted (Zhao et al., 2015). H. pylori infection activates NF- $\kappa$ B, increases IL6 secretion, and promotes AP-1 and STAT3, which induce transcription of $\mathrm{miR}-21$; and it plays an oncogenic role in cancer development, including proliferation, migration, and apoptosis (Zhang et al., 2008; Belair et al., 2009; Ma and Tao, 2012). MiR-21 activates COX2, which participates in preneoplastic gastric lesions that are resistant to apoptosis (Shukla et al., 2016). MiR-3178 decreases the expression of TRAF3, TNF- $\alpha$, and IL-6, accompanied by the inhibition of NF- $\kappa \mathrm{B}$ signals, while $H$. pylori infection presents Tip- $\alpha$ to inhibit miR-3178 expression, thus activating the NF- $\kappa$ B signal and promoting inflammation and carcinogenesis (Zou et al., 2017). NF- $\kappa \mathrm{B}$ is also involved in the upregulation of miR223-3p by binding to the promoter of primary miR-223-3p. H. pylori infection promotes FZD7 (Frizzled 7) expression, which is an important coreceptor in the WNT signaling pathway, promoting cell proliferation, while miR-27b targets the $3^{\prime}$ UTR of FZD7 to suppress FZD7 expression in GC (Geng et al., 2016). Double-stranded miR-30a is transformed to two singlestranded miRNAs, including miR-30a-3p and miR-30a-5p. The former regulates $\beta$-catenin nuclear translocation by inhibiting COX2, while the latter targets BCL9 to regulate TCF/LEF promoter activity. In $H$. pylori-infected GC, miR-30a plays a tumor suppressor role in cancer development (Liu et al., 2017). H. pylori infection in GC increases the level of miR99b, which inhibits mTOR expression to upregulate autophagy, inducing intracellular $H$. pylori elimination and cell death (Yang L. et al., 2018).

However, there are also reports that miR-146 and miRlet-7 are significantly downregulated in $H$. pylori-infected GC (Ranjbar et al., 2018). MiR-146a acts as a tumor suppressor, as it reduces the expression of pro-metastatic genes like L1CAM and ROCK1 (Shomali et al., 2019). Some miRNAs have their own target genes and regulate the progression of GC at various time points. MiR-152 and miR-200b inhibit B7$\mathrm{H} 1$ [a member of the B7 costimulatory family of molecules that bind to programmed death-1 (PD-1) and play a critical immunoregulatory role in the cell-mediated immune response] expression by binding to its $3^{\prime} \mathrm{UTR}$, while $H$. pylori infection inhibits the ability of the miRNA to promote B7-H1 expression (Xie et al., 2017). H. pylori infection in GC tissue promotes miR-222-3p expression, decreasing the levels of its target HIPK2 (homeodomain-interacting protein kinase 2) and thus promoting proliferation and invasion and inhibiting apoptosis (Tan et al., 2018). Another analysis showed no significant difference in the expression of miR-222 between $H$. pylori-positive and H. pylori-negative GC tissues (Noormohammad et al., 2016). H. pylori infection leads to miR-328 downregulation and CD44v9 (CD44, variant 9) upregulation, and this upregulation can enhance reactive oxygen species resistance to prevent cell death (Ishimoto et al., 2015). Clinical statistical analysis showed that miR-375 downregulation and upregulation of its target JAK2 (Janus kinase 2) were associated with $H$. pylori infection in patients with GC $(p<0.05)$ (Chen B. et al., 2017). MiR375 is regarded as an inhibitor of $H$. pylori-induced gastric carcinogenesis by inhibiting the expression of lncRNA SOX2OT (SOX2 overlapping transcript) and SOX2, a master regulator of the pluripotency of cancer stem cells (Shafiee et al., 2016). MiR-375 regulates the JAK2-STAT3 pathway, which affects BCL2 and TWIST1 expression to promote neoplastic transformation (Miao et al., 2014). A special miRNA requiring attention in $H$. pylori infection is the elevation of miR-30d expression, which enhances $H$. pylori intracellular survival via downregulation of the autophagy pathway (validated by several genes like ATG2B and BECN1) (Yang X. et al., 2016) (summarized in Table 2).

\section{MicroRNAs Influence the Drug Resistance of Helicobacter pylori-Infected Gastric Cancer}

Many miRNAs are also related to drug resistance and impact the treatment of GC. Early $H$. pylori eradication and aspirin use have been suggested to prevent development of the intestinal metaplasia in GC (Wang et al., 2019), while miR-21, 155, and 233 have been suggested to have a positive correlation with $H$. pylori infection to spasmolytic polypeptide-expressing metaplasia (SPEM) (Hyun Lim et al., 2018). H. pylori infection elevates miR-21 expression, while COE (Celastrus orbiculatus) inhibits this upregulation. COE upregulates PDCD4 expression by decreasing the methylation of its promoter and inhibits 
TABLE 2 | Function of miRNA in Helicobacter pylori-infected gastric cancer.

\begin{tabular}{|c|c|c|c|c|c|}
\hline MicroRNA (host gene) & Target gene of miRNA & $\begin{array}{l}\text { Effector produced by } \\
\text { H. pylori }\end{array}$ & $\begin{array}{l}\text { Expression after } \mathrm{H} \text {. } \\
\text { pylori infection }\end{array}$ & $\begin{array}{l}\text { Function to cancer after } \\
\text { infection }\end{array}$ & References \\
\hline MiR-34b & & & Down & & Tahara et al., 2019 \\
\hline MiR-34c & & & Down & & Tahara et al., 2019 \\
\hline MiR-124a & IL-8, SMOX & & Down & & Tahara et al., 2019 \\
\hline MiR-133a & & & Down & & Hyun Lim et al., 2018 \\
\hline MiR-149 & COX2, PGF2, IL-6 & & Down & & Li et al., 2015 \\
\hline MiR-200a/b & & & Down & & Choi et al., 2020 \\
\hline MiR-204(TRPM3) & $\mathrm{BIRC2,NF- \kappa B}$ & & Down & Metastasis, proliferation & Chen et al., 2019 \\
\hline MiR-210 & STMN1, DIMT1 & CagA & Down & Proliferation & Kiga et al., 2014 \\
\hline MiR-490-3p(CHRM2) & SMARCD1 & & Down & $\begin{array}{l}\text { Viability, migration, invasion, } \\
\text { colony formation, cell growth }\end{array}$ & $\begin{array}{l}\text { Shen et al., 2015; Cho } \\
\text { et al., } 2016\end{array}$ \\
\hline let-7b & IL-1 $1 \beta, \| \mathrm{L}-8$, Ras oncoprotein & & Down & Immune response & $\begin{array}{l}\text { Chen et al., 2015; Wu } \\
\text { et al., 2017; Zhang } \\
\text { et al., } 2017\end{array}$ \\
\hline MiR-7 & NF-кB, IKKE, RELA, FOS & & Down & Proliferation & Zhao et al., 2015 \\
\hline MiR-22 & NLRP3, IL-1 $\beta$, CCND1 & & Down & Proliferation, inflammation & Li et al., 2018 \\
\hline MiR-24-3p & & & Down & $\begin{array}{l}\text { Growth, migration, invasion, } \\
\text { apoptosis }\end{array}$ & Li et al., 2016 \\
\hline MiR-30a-3p & $\beta$-Catenin, COX2 & & Down & & Liu et al., 2017 \\
\hline MiR-30a-5p & BCL9, TCF/LEF & & Down & & Liu et al., 2017 \\
\hline MiR-34a & TLP4, TNF- $\alpha$, IL-6 & rTip- $\alpha$ & Down & Proliferation, viability & Wang et al., 2018 \\
\hline MiR-101/26 & $\begin{array}{l}\text { SOCS2, c-myc, CDK2, CDK4, } \\
\text { CDK6, CCND2, CCND3, } \\
\text { CCNE2; p14 p16, p21, p27 }\end{array}$ & & Down & Proliferation, colony formation & Zhou et al., 2015b \\
\hline MiR-106b/375 & JAK1, STAT3 & LPS & Down & & Ye et al., 2015 \\
\hline MiR-128/-148a & MMP-3/-7, E-cadherin & & Down & Migration, invasion & Yang Y. et al., 2018 \\
\hline MiR-134 & FoxM1 & CagA, PBP1A & Down & Proliferation, invasion & Huang et al., 2019 \\
\hline MiR-145 & & & Down & & Demiryas et al., 2019 \\
\hline MiR-152, miR-200b & $\mathrm{B} 7-\mathrm{H} 1$ (PDL1) & & Down & & Xie et al., 2017 \\
\hline MiR-204 & SOX4 & & Down & Invasion, proliferation & Zhou et al., 2014a \\
\hline MiR-320 & Mcl-1 & CagA & Down & Apoptosis & Noto et al., 2013 \\
\hline MiR-328 & $\mathrm{CD} 44 \mathrm{v} 9$ & & Down & Cell death & Ishimoto et al., 2015 \\
\hline MiR-375 & $\begin{array}{l}\text { SOX2OT, SOX2, JAK2-STAT3, } \\
\text { BCL2, TWSIT1 }\end{array}$ & & Down & Cell proliferation, migration & $\begin{array}{l}\text { Miao et al., 2014; Ye } \\
\text { et al., 2015; Shafiee } \\
\text { et al., 2016; Chen B. } \\
\text { et al., } 2017\end{array}$ \\
\hline MiR-490-3p & & & Down & Lymph node metastasis & Qu et al., 2017 \\
\hline MiR-1915 & RAGE & & Down & Proliferation, invasion, migration & Xu et al., 2019 \\
\hline MiR-3178 & TRAF3, TNF- $\alpha$ and IL-6, NF-кB & Tip- $\alpha$ & Down & Inflammation & Zou et al., 2017 \\
\hline MiR-141 & KEAP1 & & Down & & Zhou et al., 2014b \\
\hline MiR-143-3p & AKT2 & & Down & & Wang F. et al., 2017 \\
\hline MiR-370 & FoxM1 & CagA & Down & & Feng et al., 2013 \\
\hline MiR-21 & RECK & & Up & & Zhang et al., 2008 \\
\hline MiR-30d & $\begin{array}{l}\text { ATG2B, ATG5, ATG12, BECN1, } \\
\text { BNIP3L }\end{array}$ & & Up & Autophagy & Yang X. et al., 2016 \\
\hline MiR-99b & mTOR & & Up & Autophagy, cell death & Yang L. et al., 2018 \\
\hline MiR-194 & & & Up & & Demiryas et al., 2019 \\
\hline MiR-146a & $\begin{array}{l}\text { IRAK1, TRAF6, MyD88, TLRs, } \\
\text { NF-кB, L1CAM, ROCK1 }\end{array}$ & & Up & Metastasis & $\begin{array}{l}\text { Zabaglia et al., 2018; Li } \\
\text { et al., 2019; Shomali } \\
\text { et al., 2019 }\end{array}$ \\
\hline $\begin{array}{l}\text { MiR-150-5p, miR-155-5p, } \\
\text { and miR-3163 }\end{array}$ & POLD3, MSH2, MSH3 & & Up & DNA damage, DNA repair & Santos et al., 2017 \\
\hline MiR-155 & KLF4 & CagA & Up & EMT, growth & Ou et al., 2019 \\
\hline MiR-221,222 & RECK, PTEN & & Up & Growth, invasion & Liu et al., 2015 \\
\hline
\end{tabular}


TABLE 2 | Continued

\begin{tabular}{|c|c|c|c|c|c|}
\hline MicroRNA (host gene) & Target gene of miRNA & $\begin{array}{l}\text { Effector produced by } \\
\text { H. pylori }\end{array}$ & $\begin{array}{l}\text { Expression after } \mathrm{H} . \\
\text { pylori infection }\end{array}$ & $\begin{array}{l}\text { Function to cancer after } \\
\text { infection }\end{array}$ & References \\
\hline MiR-223-3p & $\begin{array}{l}\text { HIPK2, NF-кB, ARID1A, } \\
\text { E-cadherin }\end{array}$ & CagA & Up & $\begin{array}{l}\text { Proliferation, invasion, } \\
\text { apoptosis }\end{array}$ & $\begin{array}{l}\text { Ma et al., 2014; Tan } \\
\text { et al., 2018; Yang F. } \\
\text { et al., 2018- + }\end{array}$ \\
\hline MiR-21 & & & Up & EMT, inflammation & Zhu et al., 2019 \\
\hline MiR-135b-5p & NF-кB, KLF4 & & Up & Apoptosis & Shao et al., 2019 \\
\hline MiR-185 & DNMT1, EZH2 & & Up & & Yoon et al., 2013 \\
\hline MiR-223 & FBXW7 & & Up & & Zhou et al., 2015a \\
\hline MiR-1289 & $\mathrm{HK} \alpha$ (H-K-ATPase $\alpha$ subunit) & CagA, SLT & Up & Transient hypochlorhydria & Zhang et al., 2014 \\
\hline MiR-223-3p & & & Up & & Yang F. et al., 2018 \\
\hline MiR-29a-3p & A20 & & Up & & Sun et al., 2018 \\
\hline MiR-320a, miR-4496 & $\beta$-Catenin, ABCG2 & CagA & & Metastasis & Kang et al., 2016, 2017 \\
\hline MiR-490-3p & SMARCD1 & & & & Shen et al., 2015 \\
\hline MiR-155 & Rheb & & & $\begin{array}{l}\text { Autophagy, immune system } \\
\text { response }\end{array}$ & Wu et al., 2016 \\
\hline MiR-29b-1-5p & PHLPP1, MMP2, MMP9 & & & & Datta et al., 2018 \\
\hline
\end{tabular}

H. pylori-induced inflammation and EMT (Zhu et al., 2019). H. pylori infection enhances miR-135b-5p expression in a TNF- $\alpha$-induced NF- $\kappa \mathrm{B}$-dependent manner and binds to KLF4 to attenuate its expression. The miRNA suppresses apoptosis and induces cisplatin resistance (Shao et al., 2019). H. pylori infection downregulates miR-141, thus reducing its target KEAP1, which enhances cisplatin resistance (Zhou et al., 2014b). GKN1 suppresses miR-185, which directly targets DNMT1 and EZH2 and exerts an anti-tumor effect together with 5-fluorouracil on tumor cell growth, while $H$. pylori infection causes GKN1 (Gastrokine 1) downregulation in GC cells (Yoon et al., 2013). H. pylori-infection elevates miR-223 expression, and it targets the $3^{\prime}$ UTR of FBXW7 to modulate its expression and the G1/S transition of the cell cycle. Additionally, miR-223 shows cisplatin resistance, which can be reversed by overexpression of FBXW7 (Zhou et al., 2015a). Accompanied by H. pylori infection, CagA induces chemoresistance and CIC (cancerinitiating cell) properties like self-renewal and tumor-initiating capacity, while miR-320a and miR-4496 target $\beta$-catenin and ABCG2 (ATP-binding cassette, subfamily G, and member 2) at the transcriptional and posttranscriptional levels to attenuate CagA induction. Furthermore, the combination treatment of miR-320a/-4496 with 5-fluorouracil in an orthotopic mouse

TABLE 3 | Drug resistance-associated miRNA in Helicobacter pylori-infected gastric cancer.

\begin{tabular}{lcc}
\hline MicroRNA & Associated medicine & References \\
\hline MiR-124a & 5-Azacytidine & Tahara et al., 2019 \\
MiR-21, 155, and 233 & Spasmolytic polypeptide & Kuo et al., 2019 \\
MiR-21 & Celastrus orbiculatus & Zhu et al., 2019 \\
MiR-135b-5p & Cisplatin & Shao et al., 2019 \\
MiR-141 & Cisplatin & Zhou et al., 2014b \\
MiR-185 & 5-Fluorouracil & Yoon et al., 2013 \\
MiR-223 & Cisplatin & Zhou et al., 2015a \\
MiR-320a, miR-4496 & 5-Fluorouracil & Kang et al., 2016, 2017
\end{tabular}

model has been shown to attenuate gastric tumorigenesis and metastatic potential (Kang et al., 2017). Rebamipide upregulates miR-320a/-4496 to suppress $H$. pylori CagA-induced $\beta$-catenin and CIC marker gene expression. This treatment could enhance sensitivity to chemotherapeutic drugs (Kang et al., 2016). It was found that the expression of miR-320a was downregulated in GC cells, and the sensitivity of GC cells to DDP was enhanced by directly regulating to ADAM10 (Ge et al., 2017). And miR29b can enhance the sensitivity of GC cell by directly targeting PI3K/Akt pathway (Chen et al., 2015). In addition, the low expression of miR-125b (Zhang et al., 2017), miR-181a (Zhao et al., 2016), miR-22 (Qian et al., 2017), and so on was found to be associated with DDP resistance in GC. On the other hand, the development of MDR is also a key cause of treatment failure in GC, and it was found UCA could increase MDR of GC by directly downregulating miR-27b (Fang et al., 2016) (summarized in Table 3).

Several miRNAs have been found to be biomarkers for the prognosis of GC. MiR-490-3p is downregulated in H. pyloripositive GC and is significantly correlated with lymph node metastasis and clinical stage (Qu et al., 2017). According to microarrays and RT-PCR, miR-145 is downregulated and miR-194 is upregulated significantly in $H$. pylori-positive GC (Demiryas et al., 2019). Urinary miR-6807-5p and miR-6856-5p perform as biomarkers when combined with $H$. pylori infection $(\mathrm{ACU}=0.885)$ in the detection of GC (Iwasaki et al., 2019). The mechanism remains unclear. It may provide doctors with another way to quickly detect GC in the future.

\section{CONCLUSION}

There are presently many reports on the mechanism of ncRNAs in relation to GC, but research on the mechanism related to Helicobacter pylori infection has not attracted sufficient attention. For instance, GClnc1 (GC-associated lncRNA 1) has been regarded as a modular scaffold of WDR45 and KAT2A 
histone modifiers. It can regulate the localization and histone modification of SOD2. GClnc1 shows a strong correlation with the carcinogenesis, invasion, growth, and prognosis of GC. Another is clinical analysis showed that $78 \%$ of GC patients with higher GClncl expression are H. pylori-infected. The mechanism underlying the interaction between $H$. pylori and GClnc1 merits further exploration (Sun et al., 2016).

Most current research mainly shows the correlation and interaction (promotion or interference) of ncRNA in H. pyloriinfected GC. H. pylori infection in GC causes expression changes in miRNAs or lncRNAs, while miRNAs and lncRNAs can interact with each other. Another miRNA in turn affects the efficiency of $H$. pylori infection. Data analysis has mainly been derived from clinical data, databases, or sequencing or array analyses of H. pylori-infected normal gastric epithelial cells. In this case, a large number of research targets are obtained, but there remains a lack of further clarification of the specific molecular mechanism, which needs to be further confirmed and evaluated in animal models or in vitro experiments to provide more reliable evidence for clinical treatment. Concurrently, in analyses of clinical data, focusing on the correlation and interaction between ncRNA and various $H$. pylori virulence factors also provides a good perspective. Array and database analyses have provided large amounts of data, but they need to be further confirmed and analyzed, a stage of research that is still in the preliminary phases. NcRNA plays a very important role in the progression of $H$. pylori-infected GC. It can not only affect the chemotherapy resistance of GC but also serve as a biomarker for the prognosis of GC. As a new type of ncRNA, circRNA has been found to have the potential as a prognostic biomarker for GC (Shan et al., 2019). For example, the expression of hsa_circ_0001649 in GC was significantly lower than that in paired non-tumor tissues. What is more, compared with preoperative plasma samples, the expression level of hsa_circ_0001649 was upregulated after

\section{REFERENCES}

Acunzo, M., Romano, G., Wernicke, D., and Croce, C. M. (2015). MicroRNA and cancer-a brief overview. Adv. Biol. Regul. 57, 1-9. doi: 10.1016/j.jbior.2014. 09.013

Amieva, M. R., and El-Omar, E. M. (2008). Host-bacterial interactions in Helicobacter pylori infection. Gastroenterology 134, 306-323. doi: 10.1053/j. gastro.2007.11.009

Atherton, J. C., and Blaser, M. J. (2009). Coadaptation of Helicobacter pylori and humans: ancient history, modern implications. J. Clin. Invest. 119, 2475-2487. doi: 10.1172/JCI38605

Backert, S., Neddermann, M., Maubach, G., and Naumann, M. (2017). Pathogenesis of Helicobacter pylori infection. Helicobacter 21, 19-25. doi: 10. 1111/hel.12335

Bartel, D. P. (2004). MicroRNAs: genomics, biogenesis, mechanism, and function. Cell 116, 281-297. doi: 10.1016/s0092-8674(04)00045-5

Belair, C., Darfeuille, F., and Staedel, C. (2009). Helicobacter pylori and gastric cancer: possible role of microRNAs in this intimate relationship. Clin. Microbiol. Infect. 15, 806-812. doi: 10.1111/j.1469-0691.2009.02960.x

Blaser, M. J., and Atherton, J. C. (2004). Helicobacter pylori persistence: biology and disease. J. Clin. Invest. 113, 321-333. doi: 10.1172/JCI20925

Burd, C. E., Jeck, W. R., Liu, Y., Sanoff, H. K., Wang, Z., and Sharpless, N. E. (2010). Expression of linear and novel circular forms of an INK4/ARF-associated non-coding RNA correlates with atherosclerosis risk. PLoS Genet. 6:e1001233. doi: $10.1371 /$ journal.pgen.1001233 surgery, suggesting that hsa_circ_0001649 may be a follow-up indicator for GC patients after surgery (Li et al., 2017). And CircPVT1 levels were observed to be independent prognostic indicators of overall survival and DFS in GC patients (Chen J. et al., 2017). At present, ncRNAs including circRNAs, miRNAs, and IncRNAs have the potential to be used as prognostic biomarkers for GC, and previous studies have shown that many ncRNAs can accurately predict the prognosis of patients, which is of great significance to both doctors and patients. However, more work and efforts are still needed to be done for clinical application. Actually, we can found that ncRNA has been studied much longer than lncRNAs, and its experimental technique is more mature. And at the same time, there are more research results. But it could not prove that miRNA plays a more important role than lncRNAs in $H$. pylori-infected GC. The mechanism about lncRNAs still needs to be explored. And there are many kinds of ncRNAs in which their function has not been discovered in $H$. pylori-infected GC, and it would be a very promising research direction in the field of biomedicine.

\section{AUTHOR CONTRIBUTIONS}

CW and YH wrote the manuscript. SW, BZ, and YB revised the manuscript. $\mathrm{YH}$ and QL was responsible for searching the references. CY projected and edited the manuscript. XX and SY reviewed the manuscript. All authors read and approved the final manuscript.

\section{FUNDING}

This work was supported by the National Natural Science Foundation of China (No. 81773037).

Chen, B., Guo, S., Yu, Z., Feng, Y., and Hui, L. (2017). Downregulation of microRNA-375, combined with upregulation of its target gene Janus kinase 2, predicts unfavorable prognosis in patients with gastric cancer. Int. J. Clin. Exp. Pathol. 10, 11106-11113.

Chen, D., Feng, L., Ye, R., He, Y., and Wang, Y. (2015). MiR-29b Reduces Cisplatin Resistance of Gastric Cancer Cell by Targeting PI3K/Akt Pathway. Zhongguo Yi Xue Ke Xue Yuan Xue Bao 37, 514-519. doi: 10.3881/j.issn.1000-503X.2015. 05.005

Chen, J., Li, Y., Zheng, Q., Bao, C., He, J., Chen, B., et al. (2017). Circular RNA profile identifies circPVT1 as a proliferative factor and prognostic marker in gastric cancer. Cancer Lett. 388, 208-219. doi: 10.1016/j.canlet.2016.12.006

Chen, P., Guo, H., Wu, X., Li, J., Duan, X., Ba, Q., et al. (2019). Epigenetic silencing of microRNA-204 by Helicobacter pylori augments the NF-kappaB signaling pathway in gastric cancer development and progression. Carcinogenesis 41, 430-441. doi: 10.1093/carcin/bgz143

Chen, Q., and Crosa, J. H. (1996). Antisense RNA, fur, iron, and the regulation of iron transport genes in Vibrio anguillarum. J. Biol. Chem. 271, 18885-18891. doi: $10.1074 /$ jbc.271.31.18885

Cho, C. H., Yu, J., and Wu, W. (2016). Identification of pathogenic microRNAs in Helicobacter pylori-associated gastric cancer using a combined approach of animal study and clinical sample analysis. Hong Kong Med. J. 6, 13-18.

Choi, I. J., Kook, M. C., Kim, Y. I., Cho, S. J., Lee, J. Y., Kim, C. G., et al. (2018). Helicobacter pylori Therapy for the Prevention of Metachronous Gastric Cancer. N. Engl. J. Med. 378, 1085-1095. doi: 10.1056/NEJMoa170 8423 
Choi, J. M., Kim, S. G., Yang, H., Lim, J. H., Cho, N., Kim, W., et al. (2020). Helicobacter pylori Eradication Can Reverse the Methylation-Associated Regulation of miR-200a/b in Gastric Carcinogenesis. Gut Liver 14, 571-580. doi: $10.5009 /$ gnl19299

Chung, S., Nakagawa, H., Uemura, M., Piao, L., Ashikawa, K., and Hosono, N. (2011). Association of a novel long non-coding RNA in 8q24 with prostate cancer susceptibility. Cancer Sci. 102, 245-252. doi: 10.1111/j.1349-7006.2010. 01737.x

Clyne, M., Labigne, A., and Drumm, B. (1995). Helicobacter pylori requires an acidic environment to survive in the presence of urea. Infect. Immun. 63, 1669-1673. doi: 10.1128/IAI.63.5.1669-1673.199

Datta, C., Subuddhi, A., Kumar, M., Lepcha, T. T., Chakraborty, S., Jana, K., et al. (2018). Genome-wide mRNA-miRNA profiling uncovers a role of the microRNA miR-29b-1-5p/PHLPP1 signalling pathway in Helicobacter pyloridriven matrix metalloproteinase production in gastric epithelial cells. Cell Microbiol. 20:e12859. doi: 10.1111/cmi.12859

Demiryas, S., Kocazeybek, B., Demirci, M., Caliskan, R., Kepil, N., Uysal, H., et al. (2019). Helicobacter pylori-miRNA interaction in gastric cancer tissues: first prospective study from Turkey. New Microbiol. 42, 210-220.

Dühring, U., Axmann, I. M., Hess, W. R., and Wilde, A. (2006). An internal antisense RNA regulates expression of the photosynthesis gene isiA. Proc. Natl. Acad. Sci. U. S. A. 103, 7054-7058. doi: 10.1073/pnas.0600927103

Fang, Q., Chen, X. Y., and Zhi, X. (2016). Long Non-Coding RNA (LncRNA) Urothelial Carcinoma Associated 1 (UCA1) Increases Multi-Drug Resistance of Gastric Cancer via Downregulating miR-27b. Med. Sci. Monit. 22, 3506-3513. doi: $10.12659 / \mathrm{msm} .900688$

Feng, Y., Wang, L., Zeng, J., Shen, L., Liang, X., Yu, H., et al. (2013). FoxM1 is overexpressed in Helicobacter pylori-induced gastric carcinogenesis and is negatively regulated by miR-370. Mol. Cancer Res. 11, 834-844. doi: 10.1158/ 1541-7786.MCR-13-0007

Ferlay, J., Colombet, M., Soerjomataram, I., Mathers, C., Parkin, D. M., Piñeros, M., et al. (2019). Estimating the global cancer incidence and mortality in 2018: GLOBOCAN sources and methods. Int. J. Cancer 144, 1941-1953. doi: 10.1002/ ijc. 31937

Freedberg, D. E., Toussaint, N. C., Chen, S. P., Ratner, A. J., Whittier, S., and Wang, T. C. (2015). Proton Pump Inhibitors Alter Specific Taxa in the Human Gastrointestinal Microbiome: a Crossover Trial. Gastroenterology 149, 8835.e9. doi: 10.1053/j.gastro.2015.06.043

Ge, X., Cui, H., Zhou, Y., Yin, D., Feng, Y., Xin, Q., et al. (2017). MiR-320a modulates cell growth and chemosensitivity via regulating ADAM10 in gastric cancer. Mol. Med. Rep. 16, 9664-9670. doi: 10.3892/mmr.2017.7819

Geissmann, T., Possedko, M., Huntzinger, E., Fechter, P., Ehresmann, C., and Romby, P. (2006). Regulatory RNAs as mediators of virulence gene expression in bacteria. Handb. Exp. Pharmacol. 173, 9-43. doi: 10.1007/3-540-27262-3_2

Geng, Y., Lu, X., Wu, X., Xue, L., Wang, X., Xu, J., et al. (2016). MicroRNA27b suppresses Helicobacter pylori-induced gastric tumorigenesis through negatively regulating Frizzled7. Oncol. Rep. 35, 2441-2450. doi: 10.3892/or. 2016.4572

Ghoussaini, M., Song, H., Koessler, T., Olama, A., Kote-Jarai, Z., and Driver, K. E. (2008). Multiple loci with different cancer specificities within the $8 \mathrm{q} 24$ gene desert. J. Natl. Cancer Inst. 100, 962-966. doi: 10.1093/jnci/djn190

Hayashi, Y., Tsujii, M., Wang, J., Kondo, J., Akasaka, T., Jin, Y., et al. (2013). CagA mediates epigenetic regulation to attenuate let-7 expression in Helicobacter pylori-related carcinogenesis. Gut 62, 1536-1546. doi: 10.1136/gutjnl-2011301625

He, B., Sun, H., Xu, T., Pan, Y., Lin, K., and Gao, T. (2017). Association of Genetic Polymorphisms in the LncRNAs with Gastric Cancer Risk in a Chinese Population. J. Cancer 8, 531-536. doi: 10.7150/jca.17519

Helicobacter and Cancer Collaborative Group [HCCG] (2001). Collaborative G. Gastric cancer and Helicobacter pylori: a combined analysis of 12 case control studies nested within prospective cohorts. Gut 49, 347-353. doi: 10.1136/gut. 49.3.347

Huang, L., Wang, Z., and Pan, D. (2019). Penicillinbinding protein 1A mutationpositive Helicobacter pylori promotes epithelialmesenchymal transition in gastric cancer via the suppression of microRNA134. Int. J. Oncol. 54, 916-928. doi: 10.3892/ijo.2018.4665

Hyun Lim, J., Kim, S. G., Choi, J. M., Yang, H., Kim, J. S., Jung, H. C., et al. (2018). Helicobacter pylori Is Associated with miR-133a Expression through
Promoter Methylation in Gastric Carcinogenesis. Gut Liver 12, 58-66. doi: $10.5009 /$ gnl17263

Ishimoto, T., Izumi, D., Watanabe, M., Yoshida, N., Hidaka, K., Miyake, K., et al. (2015). Chronic inflammation with Helicobacter pylori infection is implicated in CD44 overexpression through miR-328 suppression in the gastric mucosa. J. Gastroenterol. 50, 751-757. doi: 10.1007/s00535-014-1019-y

Isomoto, H., Matsushima, K., Inoue, N., Hayashi, T., Nakayama, T., Kunizaki, M., et al. (2012). Interweaving microRNAs and proinflammatory cytokines in gastric mucosa with reference to H. pylori infection. J. Clin. Immunol. 32, 290-299. doi: 10.1007/s10875-011-9626-3

Iwasaki, H., Shimura, T., Yamada, T., Okuda, Y., Natsume, M., Kitagawa, M., et al. (2019). A novel urinary microRNA biomarker panel for detecting gastric cancer. J. Gastroenterol. 54, 1061-1069. doi: 10.1007/s00535-019-01601-w

Jia, W., Zhang, J., Ma, F., Hao, S., Li, X., Guo, R., et al. (2019). Long noncoding RNA THAP9-AS1 is induced by Helicobacter pylori and promotes cell growth and migration of gastric cancer. Onco Targets Ther. 12, 6653-6663. doi: 10.2147/ OTT.S201832

Kang, D. W., Noh, Y. N., Hwang, W. C., Choi, K., and Min, D. S. (2016). Rebamipide attenuates Helicobacter pylori CagA-induced self-renewal capacity via modulation of beta-catenin signaling axis in gastric cancer-initiating cells. Biochem. Pharmacol. 113, 36-44. doi: 10.1016/j.bcp.2016.06.003

Kang, D. W., Yang, E. S., Noh, Y. N., Hwang, W. C., Jo, S., Suh, Y., et al. (2017). MicroRNA-320a and microRNA-4496 attenuate Helicobacter pylori cytotoxin-associated gene A (CagA)-induced cancer-initiating potential and chemoresistance by targeting beta-catenin and ATP-binding cassette, subfamily G, member 2. J. Pathol. 241, 614-625. doi: 10.1002/path.4866

Kiga, K., Mimuro, H., Suzuki, M., Shinozaki-Ushiku, A., Kobayashi, T., Sanada, T., et al. (2014). Epigenetic silencing of miR-210 increases the proliferation of gastric epithelium during chronic Helicobacter pylori infection. Nat. Commun. 5:4497. doi: 10.1038/ncomms5497

Kuo, H., Chang, W., Yeh, Y., Cheng, H., Tsai, Y., Wu, C., et al. (2019). Spasmolytic polypeptide-expressing metaplasia associated with higher expressions of miR21,155 , and 223 can be regressed by Helicobacter pylori eradication in the gastric cancer familial relatives. Helicobacter 24:e12578. doi: 10.1111/hel.12578

Lan, W. G., Xu, D., Xu, C., Ding, C., Ning, F. L., Zhou, Y., et al. (2016). Silencing of long non-coding RNA ANRIL inhibits the development of multidrug resistance in gastric cancer cells. Oncol Rep. 36, 263-270. doi: 10.3892/or.2016.4771

Li, N., Wang, J., Yu, W., Dong, K., You, F., Si, B., et al. (2019). MicroRNA146a inhibits the inflammatory responses induced by interleukin17A during the infection of Helicobacter pylori. Mol. Med. Rep. 19, 1388-1395. doi: 10.3892/ mmr.2018.9725

Li, P., Shan, J., Chen, X., Zhang, D., Su, L., Huang, X., et al. (2015). Epigenetic silencing of microRNA-149 in cancer-associated fibroblasts mediates prostaglandin E2/interleukin-6 signaling in the tumor microenvironment. Cell Res. 25, 588-603. doi: 10.1038/cr.2015.51

Li, Q., Wang, N., Wei, H., Li, C., Wu, J., and Yang, G. (2016). MiR-24-3p Regulates Progression of Gastric Mucosal Lesions and Suppresses Proliferation and Invasiveness of N87 Via Peroxiredoxin 6. Dig. Dis. Sci. 61, 3486-3497. doi: 10.1007/s10620-016-4309-9

Li, S., Liang, X., Ma, L., Shen, L., Li, T., Zheng, L., et al. (2018). MiR-22 sustains NLRP3 expression and attenuates $H$. pylori-induced gastric carcinogenesis. Oncogene 37, 884-896. doi: 10.1038/onc.2017.381

Li, W., Song, Y., Zhang, H., Zhou, Z., Xie, X., Zeng, Q., et al. (2017). Decreased Expression of Hsa_circ_00001649 in Gastric Cancer and Its Clinical Significance. Dis. Markers 2017, 1-6.

Liu, W., Song, N., Yao, H., Zhao, L., Liu, H., and Li, G. (2015). MiR-221 and miR222 Simultaneously Target RECK and Regulate Growth and Invasion of Gastric Cancer Cells. Med. Sci. Monit. 21, 2718-2725. doi: 10.12659/MSM.894324

Liu, X., Ji, Q., Zhang, C., Liu, X., Liu, Y., Liu, N., et al. (2017). MiR-30a acts as a tumor suppressor by double-targeting COX-2 and BCL9 in H. pylori gastric cancer models. Sci. Rep. 7:7113. doi: 10.1038/s41598-017-07193-w

Livny, J., and Waldor, M. K. (2007). Identification of small RNAs in diverse bacterial species. Curr. Opin. Microbiol. 10, 96-101. doi: 10.1016/j.mib.2007. 03.005

Ma, L., Chen, Y., Zhang, B., and Liu, G. (2014). Increased microRNA-223 in Helicobacter pylori-associated gastric cancer contributed to cancer cell proliferation and migration. Biosci. Biotechnol. Biochem. 78, 602-608. doi: 10. $1080 / 09168451.2014 .895661$ 
Ma, Y., and Tao, H. (2012). Microribonucleic acids and gastric cancer. Cancer Sci. 103, 620-625. doi: 10.1111/j.1349-7006.2011.02185.x

Majdalani, N., Vanderpool, C. K., and Gottesman, S. (2005). Bacterial small RNA regulators. Crit. Rev. Biochem. Mol. Biol. 40, 93-113. doi: 10.1080/ 10409230590918702

Malfertheiner, P., Megraud, F., O’Morain, C. A., Gisbert, J. P., Kuipers, E. J., Axon, A. T., et al. (2017). Management of Helicobacter pylori infection-the Maastricht V/Florence Consensus Report. Gut 66, 6-30. doi: 10.1136/gutjnl-2016-312288

Mera, R. M., Bravo, L. E., Camargo, M. C., Bravo, J. C., Delgado, A. G., Romero-Gallo, J., et al. (2018). Dynamics of Helicobacter pylori infection as a determinant of progression of gastric precancerous lesions: 16-year follow-up of an eradication trial. Gut 67, 1239-1246. doi: 10.1136/gutjnl-2016-311685

Meyer-Rosberg, K., Scott, D. R., Rex, D., Melchers, K., and Sachs, G. (1996). The effect of environmental $\mathrm{pH}$ on the proton motive force of Helicobacter pylori. Gastroenterology 111, 886-900. doi: 10.1016/s0016-5085(96)70056-2

Miao, L., Liu, K., Xie, M., Xing, Y., and Xi, T. (2014). MiR-375 inhibits Helicobacter pylori-induced gastric carcinogenesis by blocking JAK2-STAT3 signaling. Cancer Immunol. Immunother. 63, 699-711. doi: 10.1007/s00262-014-1550-y

Mitarai, N., Andersson, A., Krishna, S., Semsey, S., and Sneppen, K. (2007). Efficient degradation and expression prioritization with small RNAs. Phys. Biol. 4, 164-171. doi: 10.1088/1478-3975/4/3/003

Morello, J. A. (1999). Clinical Microbiology Reviews: genesis of a journal. Clin. Microbiol. Rev. 12, 183-186.

Murray-Stewart, T., Sierra, J. C., Piazuelo, M. B., Mera, R. M., Chaturvedi, R., Bravo, L. E., et al. (2016). Epigenetic silencing of miR-124 prevents spermine oxidase regulation: implications for Helicobacter pylori-induced gastric cancer. Oncogene 35, 5480-5488. doi: 10.1038/onc.2016.91

Noormohammad, M., Sadeghi, S., Tabatabaeian, H., Ghaedi, K., Talebi, A., Azadeh, M., et al. (2016). Upregulation of miR-222 in both Helicobacter pylori- infected and noninfected gastric cancer patients. J. Genet 95, 991-995. doi: 10.1007/ s12041-016-0728-9

Noto, J. M., Piazuelo, M. B., Chaturvedi, R., Bartel, C. A., Thatcher, E. J., Delgado, A., et al. (2013). Strain-specific suppression of microRNA-320 by carcinogenic Helicobacter pylori promotes expression of the antiapoptotic protein Mcl-1. Am. J. Physiol. Gastrointest. Liver Physiol. 305, G786-G796. doi: 10.1152/ajpgi. 00279.2013

Opdyke, J. A., Kang, J., and Storz, G. (2004). A small-RNA regulator of acid response genes in Escherichia coli. J. Bacteriol. 186, 6698-6705. doi: 10.1128/ JB.186.20.6698-6705.2004

Ou, Y., Ren, H., Zhao, R., Song, L., Liu, Z., Xu, W., et al. (2019). Helicobacter pylori CagA promotes the malignant transformation of gastric mucosal epithelial cells through the dysregulation of the miR-155/KLF4 signaling pathway. Mol. Carcinog. 58, 1427-1437. doi: 10.1002/mc.23025

Pachathundikandi, S. K., Tegtmeyer, N., and Backert, S. (2013). Signal transduction of Helicobacter pylori during interaction with host cell protein receptors of epithelial and immune cells. Gut Microbes 4, 454-474. doi: 10.4161/gmic.27001

Pang, Q., Ge, J., Shao, Y., Sun, W., Song, H., Xia, T., et al. (2014). Increased expression of long intergenic non-coding RNA LINC00152 in gastric cancer and its clinical significance. Tumour Biol. 35, 5441-5447. doi: 10.1007/s13277014-1709-3

Pernitzsch, S., and Sharma, C. M. (2012). Transcriptome complexity and riboregulation in the human pathogen Helicobacter pylori. Front. Cell Infect. Microbiol. 2:14. doi: 10.3389/fcimb.2012.00014

Pernitzsch, S. R., Tirier, S. M., Beier, D., and Sharma, C. M. (2014). A variable homopolymeric G-repeat defines small RNA-mediated posttranscriptional regulation of a chemotaxis receptor in Helicobacter pylori. Proc. Natl. Acad. Sci. U. S. A. 111, e501-e510. doi: 10.1073/pnas.1315152111

Petra, C. V., Rus, A., and Dumitraşcu, D. L. (2017). Gastric microbiota: tracing the culprit. Clujul Med. 90, 369-376. doi: 10.15386/cjmed-854

Pflock, M., Dietz, P., Schär, J., and Beier, D. (2004). Genetic evidence for histidine kinase HP165 being an acid sensor of Helicobacter pylori. FEMS Microbiol. Lett. 234, 51-61. doi: 10.1016/j.femsle.2004.03.023

Pflock, M., Kennard, S., Delany, I., Scarlato, V., and Beier, D. (2005). Acidinduced activation of the urease promoters is mediated directly by the ArsRS two-component system of Helicobacter pylori. Infect. Immun. 73, 6437-6445. doi: 10.1128/IAI.73.10.6437-6445.2005

Polakovicova, I., Jerez, S., Wichmann, I. A., Sandoval-Bórquez, A., CarrascoVéliz, N., and Corvalán, A. H. (2018). Role of microRNAs and Exosomes in
Helicobacter pylori and Epstein-Barr Virus Associated Gastric Cancers. Front. Microbiol. 9:636. doi: 10.3389/fmicb.2018.00636

Qian, X., Xu, W., Xu, J., Shi, Q., Li, J., Weng, Y., et al. (2017). Enolase 1 stimulates glycolysis to promote chemoresistance in gastric cancer. Oncotarget 8, 47691-47708. doi: 10.18632/oncotarget.17868

Qu, M., Li, L., and Zheng, W. (2017). Reduced miR-490-3p expression is associated with poor prognosis of Helicobacter pylori induced gastric cancer. Eur. Rev. Med. Pharmacol. Sci. 21, 3384-3388.

Ranjbar, R., Hesari, A. R., Ghasemi, F., and Sahebkar, A. (2018). Expression of microRNAs and IRAK1 pathway genes are altered in gastric cancer patients with Helicobacter pylori infection. J. Cell Biochem. 119, 7570-7576. doi: 10. $1002 /$ jcb. 27067

Ransohoff, J., Wei, Y., and Khavari, P. A. (2018). The functions and unique features of long intergenic non-coding RNA. Nat. Rev. Mol. Cell Biol. 19, 143-157. doi: $10.1038 / \mathrm{nrm} .2017 .104$

Rieder, R., Reinhardt, R., Sharma, C., and Vogel, J. (2012). Experimental tools to identify RNA-protein interactions in Helicobacter pylori. RNA Biol. 9, 520-531. doi: 10.4161/rna.20331

Romby, P., Vandenesch, F., and Wagner, E. (2006). The role of RNAs in the regulation of virulence-gene expression. Curr. Opin. Microbiol. 9, 229-236. doi: 10.1016/j.mib.2006.02.005

Safaralizadeh, R., Dastmalchi, N., Hosseinpourfeizi, M., and Latifi-Navid, S. (2017). Helicobacter pylori virulence factors in relation to gastrointestinal diseases in Iran. Microb. Pathog. 105, 211-217. doi: 10.1016/j.micpath.2017.02. 026

Santos, J. C., Brianti, M. T., Almeida, V. R., Ortega, M. M., Fischer, W., Haas, R., et al. (2017). Helicobacter pylori infection modulates the expression of miRNAs associated with DNA mismatch repair pathway. Mol. Carcinog. 56, 1372-1379. doi: $10.1002 / \mathrm{mc} .22590$

Shafiee, S. M., Aleyasin, S. A., Mowla, S. J., Vasei, M., and Yazdanparast, S. A. (2016). The Effect of MicroRNA-375 Overexpression, an Inhibitor of Helicobacter pylori-Induced Carcinogenesis, on IncRNA SOX2OT. Jundishapur J. Microbiol. 9:e23464. doi: 10.5812/jjm.23464

Shan, C., Zhang, Y., Hao, X., Gao, J., Chen, X., and Wang, K. (2019). Biogenesis, functions and clinical significance of circRNAs in gastric cancer. Mol. Cancer 18:136. doi: 10.1186/s12943-019-1069-0

Shao, L., Chen, Z., Soutto, M., Zhu, S., Lu, H., Romero-Gallo, J., et al. (2019). Helicobacter pylori-induced miR-135b-5p promotes cisplatin resistance in gastric cancer. FASEB J. 33, 264-274. doi: 10.1096/fj.201701456RR

Sharma, C. M., and Vogel, J. (2009). Experimental approaches for the discovery and characterization of regulatory small RNA. Curr. Opin. Microbiol. 12, 536-546. doi: 10.1016/j.mib.2009.07.00

Shen, J., Xiao, Z., Wu, W., Wang, M. H., To, K. F., Chen, Y., et al. (2015). Epigenetic silencing of miR-490-3p reactivates the chromatin remodeler SMARCD1 to promote Helicobacter pylori-induced gastric carcinogenesis. Cancer Res. 75, 754-765. doi: 10.1158/0008-5472.CAN-14-1301

Shomali, N., Mansoori, B., Mohammadi, A., Shirafkan, N., Ghasabi, M., and Baradaran, B. (2017). MiR-146a functions as a small silent player in gastric cancer. Biomed. Pharmacother. 96, 238-245. doi: 10.1016/j.biopha.2017.09.138

Shomali, N., Shirafkan, N., Duijf, P., Ghasabi, M., Babaloo, Z., Yousefi, M., et al. (2019). Downregulation of miR-146a promotes cell migration in Helicobacter pylori-negative gastric cancer. J. Cell Biochem. 120, 9495-9505. doi: 10.1002/ jcb. 28225

Shukla, S., Khatoon, J., Prasad, K. N., Rai, R. P., Singh, A. K., Kumar, S., et al. (2016). Transforming growth factor beta 1 (TGF-beta1) modulates Epstein-Barr virus reactivation in absence of Helicobacter pylori infection in patients with gastric cancer. Cytokine 77, 176-179. doi: 10.1016/j.cyto.2015. 07.023

Su, M., Erwin, A. L., Campbell, A. M., Pyburn, T. M., Salay, L. E., and Hanks, J. L. (2019). Cryo-EM Analysis Reveals Structural Basis of Helicobacter pylori VacA Toxin Oligomerization. J. Mol. Biol. 431, 1956-1965. doi: 10.1016/j.jmb.2019. 03.029

Sugano, K. (2019). Effect of Helicobacter pylori eradication on the incidence of gastric cancer: a systematic review and meta-analysis. Gastric Cancer 22, 435-445. doi: 10.1007/s10120-018-0876-0

Sugano, K., Tack, J., Kuipers, E. J., Graham, D. Y., El-Omar, E. M., Miura, S., et al. (2015). Kyoto global consensus report on Helicobacter pylori gastritis. Gut 64, 1353-1367. doi: 10.1136/gutjnl-2015-309252 
Sun, F., Ni, Y., Zhu, H., Fang, J., Wang, H., Xia, J., et al. (2018). MicroRNA29a-3p, Up-Regulated in Human Gastric Cells and Tissues with H.Pylori Infection, Promotes the Migration of GES-1 Cells via A20-Mediated EMT Pathway. Cell Physiol. Biochem. 51, 1250-1263. doi: 10.1159/00049 5502

Sun, T., He, J., Liang, Q., Ren, L., Yan, T., Yu, T., et al. (2016). LncRNA GClnc1 Promotes Gastric Carcinogenesis and May Act as a Modular Scaffold of WDR5 and KAT2A Complexes to Specify the Histone Modification Pattern. Cancer Discov. 6, 784-801. doi: 10.1158/2159-8290.CD-15-0921

Suzuki, H., and Matsuzaki, J. (2018). Gastric cancer: evidence boosts Helicobacter pylori eradication. Nat. Rev. Gastroenterol. Hepatol. 15, 458-460. doi: 10.1038/ s41575-018-0023-8

Tahara, T., Tahara, S., Horiguchi, N., Kawamura, N., Okubo, M., Nagasaka, M., et al. (2019). Gastric Mucosal Microarchitectures Associated with Irreversibility with Helicobacter pylori Eradication and Downregulation of Micro RNA (miR)124a. Cancer Invest. 37, 417-426. doi: 10.1080/07357907.2019.1663207

Tan, X., Tang, H., Bi, J., Li, N., and Jia, Y. (2018). MicroRNA-222-3p associated with Helicobacter pylori targets HIPK2 to promote cell proliferation, invasion, and inhibits apoptosis in gastric cancer. J. Cell Biochem. 119, 5153-5162. doi: $10.1002 /$ jcb. 26542

Tomlinson, I., Webb, E., Carvajal-Carmona, L., Broderick, P., Kemp, Z., and Spain, S. (2007). A genome-wide association scan of tag SNPs identifies a susceptibility variant for colorectal cancer at 8q24.21. Nat. Genet. 39, 984-988. doi: 10.1038/ ng2085

Tramonti, A., Canio, M. D., and Biase, D. D. (2008). GadX/GadW-dependent regulation of the Escherichia coli acid fitness island: transcriptional control at the gadY-gadW divergent promoters and identification of four novel $42 \mathrm{bp}$ GadX/GadW-specific binding sites. Mol. Microbiol. 70, 965-982. doi: 10.1111/j. 1365-2958.2008.06458.x

Valentin-Hansen, P., Eriksen, M., and Udesen, C. (2004). The bacterial Sm-like protein Hfq: a key player in RNA transactions. Mol. Microbiol. 51, 1525-1533. doi: 10.1111/j.1365-2958.2003.03935.x

Vannini, A., Roncarati, D., and Danielli, A. (2016). The cag-pathogenicity island encoded CncR1 sRNA oppositely modulates Helicobacter pylori motility and adhesion to host cells. Cell Mol. Life Sci. 73, 3151-3168. doi: 10.1007/s00018016-2151-z

Vogel, J., and Luisi, B. F. (2011). Hfq and its constellation of RNA. Nat. Rev. Microbiol. 9, 578-589. doi: 10.1038/nrmicro2615

Vogel, J., and Wagner, E. (2007). Target identification of small noncoding RNAs in bacteria. Curr. Opin. Microbiol. 10, 262-270. doi: 10.1016/j.mib.2007.06.001

Wang, F., Liu, J., Zou, Y., Jiao, Y., Huang, Y., Fan, L., et al. (2017). MicroRNA-143$3 p$, up-regulated in $\mathrm{H}$. pylori-positive gastric cancer, suppresses tumor growth, migration and invasion by directly targeting AKT2. Oncotarget 8, 28711-28724. doi: 10.18632 /oncotarget.15646

Wang, L., Chunyan, Q., Zhou, Y., He, Q., Ma, Y., Ga, Y., et al. (2017). BCAR4 increase cisplatin resistance and predicted poor survival in gastric cancer patients. Eur. Rev. Med. Pharmacol. Sci. 21, 4064-4070.

Wang, W., Gu, C., Li, R., Xu, Z., Yu, J., Ye, Y., et al. (2019). Long non-coding RNA CASC19 is associated with the progression and prognosis of advanced gastric cancer. Aging 11, 5829-5847. doi: 10.18632/aging.102190

Wang, Y., Zhang, C., and He, X. (2018). Minor allele of rs1057317 polymorphism in TLR4 is associated with increased risk of Helicobacter pylori -induced gastric cancer. J. Cell Biochem. 120, 1969-1978. doi: 10.1002/jcb.27493

Watari, J., Ito, C., Shimoda, T., Tomita, T., Oshima, T., Fukui, H., et al. (2019). DNA methylation silencing of microRNA gene methylator in the precancerous background mucosa with and without gastric cancer: analysis of the effects of H. pylori eradication and long-term aspirin use. Sci. Rep. 9:12559. doi: 10.1038/ s41598-019-49069-1

Wen, Y., Feng, J., and Sachs, G. (2013). Helicobacter pylori 5'ureB-sRNA, a cis-encoded antisense small RNA, negatively regulates ure $\mathrm{AB}$ expression by transcription termination. J. Bacteriol. 195, 444-452. doi: 10.1128/JB.010 22-12

Wen, Y., Feng, J., Scott, D. R., Marcus, E. A., and Sachs, G. (2006). Involvement of the HP0165-HP0166 two-component system in expression of some acidicpH-upregulated genes of Helicobacter pylori. J. Bacteriol. 188, 1750-1761. doi: 10.1128/JB.188.5.1750-1761.2006

Wen, Y., Feng, J., Scott, D. R., Marcus, E. A., and Sachs, G. (2011). A cis-encoded antisense small RNA regulated by the HP0165-HP0166 two-component system controls expression of ureB in Helicobacter pylori. J. Bacteriol. 193, 40-51. doi: 10.1128/JB.00800-10

Wilusz, J., Sunwoo, H., and Spector, D. (2009). Long noncoding RNAs: functional surprises from the RNA world. Genes Dev. 23, 1494-1504. doi: 10.1101/gad. 1800909

Wu, K., Zhu, C., Yao, Y., Wang, X., Song, J., and Zhai, J. (2016). MicroRNA-155enhanced autophagy in human gastric epithelial cell in response to Helicobacter pylori. Saudi J. Gastroenterol. 22, 30-36. doi: 10.4103/1319-3767.173756

Wu, Y., Xu, Q., He, C., Li, Y., Liu, J., Deng, N., et al. (2017). Association of Polymorphisms in three pri-miRNAs that Target Pepsinogen C with the Risk and Prognosis of Gastric Cancer. Sci. Rep. 7:39528. doi: 10.1038/srep39528

Xie, G., Li, W., Li, R., Wu, K., Zhao, E., Zhang, Y., et al. (2017). Helicobacter Pylori Promote B7-H1 Expression by Suppressing miR-152 and miR-200b in Gastric Cancer Cells. PLoS One 12:e0168822. doi: 10.1371/journal.pone.0168822

Xu, Q., Chen, T.-J., He, C.-Y., Sun, L. P., Liu, J.-W., Yuvan, Y., et al. (2017). MiR-27a rs895819 is involved in increased atrophic gastritis risk, improved gastric cancer prognosis and negative interaction with Helicobacter pylori. Sci. Rep. 7:41307. doi: 10.1038/srep41307

Xu, X., Zhang, W., Li, C. X., Gao, H., Pei, Q., Cao, B., et al. (2019). Up-Regulation of MiR-1915 Inhibits Proliferation, Invasion, and Migration of Helicobacter pylori-Infected Gastric Cancer Cells via Targeting RAGE. Yonsei Med. J. 60, 38-47. doi: 10.3349/ymj.2019.60.1.38

Yang, F., Xu, Y., Liu, C., Ma, C., Zou, S., Xu, X., et al. (2018). NF-kappaB/miR223-3p/ARID1A axis is involved in Helicobacter pylori CagA-induced gastric carcinogenesis and progression. Cell Death Dis. 9:12. doi: 10.1038/s41419-0170020-9

Yang, J., and Song, H. (2019). Identification of long noncoding RNA RP11169F17.1 and RP11-669N7.2 as novel prognostic biomarkers of stomach adenocarcinoma based on integrated bioinformatics analysis. Epigenomics 11, 1307-1321. doi: 10.2217/epi-2019-0115

Yang, L., Li, C., and Jia, Y. (2018). MicroRNA-99b promotes Helicobacter pyloriinduced autophagy and suppresses carcinogenesis by targeting mTOR. Oncol. Lett. 16, 5355-5360. doi: 10.3892/ol.2018.9269

Yang, L., Long, Y., Li, C., Cao, L., Gan, H., and Huang, K. (2015). Genome-wide analysis of long noncoding RNA profile in human gastric epithelial cell response to Helicobacter pylori. Jpn. J. Infect. Dis. 68, 63-66. doi: 10.7883/yoken.JJID. 2014.149

Yang, T., Zeng, H., Chen, W., Zheng, R., Zhang, Y., Li, Z., et al. (2016). Helicobacter pylori infection, H19 and LINC00152 expression in serum and risk of gastric cancer in a Chinese population. Cancer Epidemiol. 44, 147-153. doi: 10.1016/j. canep.2016.08.015

Yang, X., Si, R., Liang, Y., Ma, B. Q., Jiang, Z., Wang, B., et al. (2016). Mir$30 \mathrm{~d}$ increases intracellular survival of Helicobacter pylori through inhibition of autophagy pathway. World J. Gastroenterol. 22, 3978-3991. doi: 10.3748/wjg. v22.i15.3978

Yang, Y., Li, X., Du, J., Yin, Y., and Li, Y. (2018). Involvement of microRNAsMMPs-E-cadherin in the migration and invasion of gastric cancer cells infected with Helicobacter pylori. Exp. Cell. Res. 367, 196-204. doi: 10.1016/j.yexcr.2018. 03.036

Yao, Y., Jiang, Q., Jiang, L., Wu, J., Zhang, Q., Wang, J., et al. (2016). LncSGK1 induced by Helicobacter pylori infection and highsalt diet promote Th2 and Th17 differentiation in human gastric cancer by SGK1/Jun B signaling. Oncotarget 7, 20549-20560. doi: 10.18632/oncotarget.7823

Ye, F., Tang, C., Shi, W., Qian, J., Xiao, S., Gu, M., et al. (2015). A MDM2dependent positive-feedback loop is involved in inhibition of miR-375 and miR-106b induced by Helicobacter pylori lipopolysaccharide. Int. J. Cancer 136, 2120-2131. doi: 10.1002/ijc.29268

Yoon, J. H., Choi, J., Choi, W. S., Ashktorab, H., Smoot, D. T., Nam, S. W., et al. (2013). GKN1-miR-185-DNMT1 axis suppresses gastric carcinogenesis through regulation of epigenetic alteration and cell cycle. Clin. Cancer Res. 19, 4599-4610. doi: 10.1158/1078-0432.CCR-12-3675

Zabaglia, L. M., Sallas, M. L., Santos, M., Orcini, W. A., Peruquetti, R. L., Constantino, D. H., et al. (2018). Expression of miRNA-146a, miRNA-155, IL-2, and TNF- $\alpha$ in inflammatory response to Helicobacter pylori infection associated with cancer progression. Ann. Hum. Genet. 82, 135-142. doi: 10.1111/ahg. 12234

Zhang, C., Zhi, W., Lu, H., Samanta, D., Chen, I., and Gabrielson, E. (2016). Hypoxia-inducible factors regulate pluripotency factor expression 
by ZNF217- and ALKBH5-mediated modulation of RNA methylation in breast cancer cells. Oncotarget 7, 64527-64542. doi: 10.18632/oncotarget.1 1743

Zhang, H., Ahearn, T. U., Lecarpentier, J., Barnes, D., Beesley, J., and Qi, G. (2010). Genome-wide association study identifies five new breast cancer susceptibility loci. Nat. Genet. 42, 504-507. doi: 10.1038/s41588-020-0609-2

Zhang, J., Wei, J., Wang, Z., Feng, F., Wei, Z., Hou, X., et al. (2020). Transcriptome hallmarks in Helicobacter pylori infection influence gastric cancer and MALT lymphoma. Epigenomics 12, 661-671. doi: 10.2217/epi-2019-0152

Zhang, X., Yao, J., Guo, K., Huang, H., Huai, S., Ye, R., et al. (2017). The functional mechanism of miR-125b in gastric cancer and its effect on the chemosensitivity of cisplatin. Oncotarget 9, 2105-2119. doi: 10.18632/oncotarget.23249

Zhang, Y., Noto, J. M., Hammond, C. E., Barth, J. L., Argraves, W. S., Backert, S., et al. (2014). Helicobacter pylori-induced posttranscriptional regulation of $\mathrm{H}-\mathrm{K}-$ ATPase alpha-subunit gene expression by miRNA. Am. J. Physiol. Gastrointest. Liver Physiol. 306, G606-G613. doi: 10.1152/ajpgi.00333.2013

Zhang, Z., Li, Z., Gao, C., Chen, P., Chen, J., Liu, W., et al. (2008). MiR-21 plays a pivotal role in gastric cancer pathogenesis and progression. Lab. Invest. 88, 1358-1366. doi: 10.1038/labinvest.2008.94

Zhao, J., Nie, Y., Wang, H., and Lin, Y. (2016). MiR-181a suppresses autophagy and sensitizes gastric cancer cells to cisplatin. Gene 576, 828-833. doi: 10.1016/ j.gene.2015.11.013

Zhao, K., Zhang, R., Li, T., and Xiong, Z. (2019). Functional variants of lncRNA LINC00673 and gastric cancer susceptibility: a case-control study in a Chinese population. Cancer Manag. Res. 11, 3861-3868. doi: 10.2147/CMAR.S187011

Zhao, X., Lu, Y., Guo, H., Xie, H., He, J., Shen, G., et al. (2015). MicroRNA-7/NFkappaB signaling regulatory feedback circuit regulates gastric carcinogenesis. J. Cell Biol. 210, 613-627. doi: 10.1083/jcb.201501073

Zheng, P., Chen, L., Yuan, X., Luo, Q., Liu, Y., Xie, G., et al. (2017). Exosomal transfer of tumor-associated macrophage-derived miR-21 confers cisplatin resistance in gastric cancer cells. J. Exp. Clin. Cancer Res. 1336:53. doi: 10.1186/ s13046-017-0528-y

Zhong, F., Zhu, M., Gao, K., Xu, P., Yang, H., and Hu, D. (2018). Low expression of the long non-coding RNA NR_026827 in gastric cancer. Am. J. Transl. Res. 10, 2706-2711.

Zhou, X., Chen, H., Zhu, L., Hao, B., Zhang, W., Hua, J., et al. (2016). Helicobacter pylori infection related long noncoding RNA (lncRNA) AF147447 inhibits gastric cancer proliferation and invasion by targeting MUC2 and up-regulating miR-34c. Oncotarget 7, 82770-82782. doi: 10.18632/oncotarget.13165

Zhou, X., Jin, W., Jia, H., Yan, J., and Zhang, G. (2015a). MiR-223 promotes the cisplatin resistance of human gastric cancer cells via regulating cell cycle by targeting FBXW7. J. Exp. Clin. Cancer Res. 34:28. doi: 10.1186/s13046-0150145-6

Zhou, X., Li, L., Su, J., and Zhang, G. (2014a). Decreased miR-204 in H. pyloriassociated gastric cancer promotes cancer cell proliferation and invasion by targeting SOX4. PLoS One 9:e101457. doi: 10.1371/journal.pone.010 1457

Zhou, X., Su, J., Zhu, L., and Zhang, G. (2014b). Helicobacter pylori modulates cisplatin sensitivity in gastric cancer by down-regulating miR-141 expression. Helicobacter 19, 174-181. doi: 10.1111/hel.12120

Zhou, X., Xia, Y., Li, L., and Zhang, G. (2015b). MiR-101 inhibits cell growth and tumorigenesis of Helicobacter pylori related gastric cancer by repression of SOCS2. Cancer Biol. Ther. 16, 160-169. doi: 10.4161/15384047.2014.98 7523

Zhu, H., Wang, Q., Yao, Y., Fang, J., Sun, F., Ni, Y., et al. (2015). Microarray analysis of Long non-coding RNA expression profiles in human gastric cells and tissues with Helicobacter pylori Infection. BMC Med. Genomics 8:84. doi: 10.1186/s12920-015-0159-0

Zhu, X., Tian, X., Yu, C., Shen, C., Yan, T., Hong, J., et al. (2016). A long non-coding RNA signature to improve prognosis prediction of gastric cancer. Mol. Cancer 15:60. doi: 10.1016/j.gastrohep.2020.01.016

Zhu, Y., Liu, L., Hu, L., Dong, W., Zhang, M., Liu, Y., et al. (2019). Effect of Celastrus orbiculatus in inhibiting Helicobacter pylori induced inflammatory response by regulating epithelial mesenchymal transition and targeting miR21/PDCD4 signaling pathway in gastric epithelial cells. BMC Complement. Altern. Med. 19:91. doi: 10.1186/s12906-019-2504-x

Zou, M., Wang, F., Jiang, A., Xia, A., Kong, S., Gong, C., et al. (2017). MicroRNA3178 ameliorates inflammation and gastric carcinogenesis promoted by Helicobacter pylori new toxin, Tip-alpha, by targeting TRAF3. Helicobacter 22:27493095.

Conflict of Interest: The authors declare that the research was conducted in the absence of any commercial or financial relationships that could be construed as a potential conflict of interest.

Copyright (c) 2021 Wang, Hu, Yang, Wang, Zhou, Bao, Huang, Luo, Yang, Xie and Yang. This is an open-access article distributed under the terms of the Creative Commons Attribution License (CC BY). The use, distribution or reproduction in other forums is permitted, provided the original author(s) and the copyright owner(s) are credited and that the original publication in this journal is cited, in accordance with accepted academic practice. No use, distribution or reproduction is permitted which does not comply with these terms. 